\title{
Empirical Analysis on Influencing Factors of Chinese Trade Surplus with the United States
}

\author{
Wei Liu \\ ${ }^{1}$ School of Economics, Guizhou University of Finance and economics, Guiyang, Guizhou Province, \\ China
}

Keywords: trade surplus; influencing factors; empirical analysis.

\begin{abstract}
Based on analyzing the present situation of trade between China and the United States, the author investigates the influence factors of Chinese trade surplus with the US, makes an empirical analysis on these factors according to time series, and finds that FDI and the insufficient domestic demand (foreign trade dependence) of China are main factors of Chinese trade surplus. Among these factors, the most important one is China's absorption of FDI.
\end{abstract}

\section{Introduction}

Since the establishment of diplomatic relations between China and the United States, the economic and trade exchanges between the two sides have gradually recovered. China has become an essential goods supplier and the most important supplier of high-tech products for the US; the United States has become a consumer giant for commodities "made in China". In economic and trade exchanges, the two economic entities are becoming increasingly complementary. According to Chinese statistics data, in 1993, trade deficit of the United States with China occurred for the first time; since then, the U.S. trade deficit with China has continued to increase. The two sides agree that in Sino-US trade, China has taken the favorable position. The issue of US trade deficit with China has become the focus of both sides. Both parties blame each other. The United States often accuses China for currency manipulation and insufficient domestic demand; China accuses the US for under saving and over regulation on high-tech exports to China. Based on the current situation and theoretical analyses, this paper constructs an econometric model to empirically analyze the influencing factors of China's trade surplus with the United States.

\section{Literature Review}

The imbalance Sino-US trade is an important problem that affects the development of China and the United States. Domestic and foreign scholars have made many researches on that issue. C. Guedae and W.K. Won (2004) finds that, the Sino-US bilateral exchange rate cannot explain the significant role of bilateral trade between the two countries, while the exchange rate between the United States and Southeast Asian countries can explain the imbalance trade between the United States and China better.[1] T Klitgaard and K Schiele (1997) believes that the low wages of Chinese workers and their working skills, as well as government subsidies and relatively low price of goods created by economies of scale, are reasons of China's favorable position in trade with foreign economies, including the United States. [2] You Lv (2013) believes that, the biggest beneficiary of the imbalance Sino- US trade is the United States, while China gets less interests. [3] Ming-zhu Xu (2009) finds that the direct investment and industrial transfer of the United States are reasons of imbalance trade between the United States and China. [4] Jie Lv (2010) examines the impact of processing trade on the compiling of bilateral trade data. [5]

Through the literature review, the author finds that domestic and foreign scholars tend to explain reasons of imbalance Sino-US trade from aspects of exchange rate, savings rate and transfer of industry. Many scholars begin to tackle this issue from perspectives like processing trade and statistical caliber. However, there are few scholars who test the effects of processing trade on the imbalance Sino-US trade from empirical perspective. Therefore, on the basis of previous research fruits, the author made a simple analysis on this issue. The innovation of this paper is the empirical 
analysis of the impacts of China's processing trade and domestic demand (the dependence degree on foreign trade used in the model) on the imbalance Sino-US trade, and the estimation of various factors' impact degrees, including the domestic savings rate of United States. The shortcoming of this article is that the author does not know how to quantify the impact of over regulation on high-tech exports to China on the imbalance Sino-US trade.

\section{Theoretical Foundation}

The imbalance Sino-US trade is caused by the differences of factor endowment and market demand, while the theory of comparative advantage explains this point. At the same time, the Two-gap Theory considers that the imbalances of domestic investment and saving are an important reason for the imbalance international trade. The author explains the theoretical basis of the paper from theory of comparative advantage and the Two-gap Theory

The theory of comparative advantage is created by David Ricardo on the basis of Theory of Absolute Advantage created by Adam Smith. Ricardo holds that, on the basis of comparative advantages of the two economic entities, bilateral trade and division of labor can increase the welfare of both sides. The two gap model can be simply expressed as follows: I/S=X/M. In the model, I represents the investment; $\mathrm{S}$ represents savings; $\mathrm{X}$ represents the export; $\mathrm{M}$ represents the import. It can be seen from the model that the investment savings gap of an economy can lead to imbalance of international payments.

\section{Analysis of the Imbalance Sino-US Trade}

The main performance of imbalance current trade between China and the United States is that according to statistics of both sides, there is a huge imbalance in trade of goods. According to Chinese data, China has enjoyed the trade surplus with the U.S. for consecutive 22 years. The surplus volume increased from \$6 billion 285 million in 1993 to \$237 billion 264 million in 2014 by 36.75 times. In 2014, China's trade surplus with the United States was equivalent to 2.48 times of the gross domestic product of Nepal.

The imbalance of investment and savings proportions between China and the United States affects bilateral trade balance. From time to time, China and the United States remind each other the problem of domestic savings. China often requires the United States to raise its domestic savings rate. The U.S. savings rate showed a downward trend, decreased from 21\% in 2000 to 18\% in 2013, which became a target of accuse for various countries. Many countries in the international community, including China, believe that in the United States believes, the excessive consumption is an important reason for the imbalance of international payments. The United States also proposes the same expectations. They find that the savings rate of China is relatively high, and presents a long-term trend of increase. Chinese savings rate soared from $36 \%$ in 2000 to $50 \%$ in 2013 . The international community, including the United States believes that Chinese people are too frugal. Their income is deposited in large bank, which leads to the deficiency of domestic demand. It is one of the big reasons of China's surplus in the balance of payments. This may be caused by different national conditions. The financial industry in the U.S. is developed, while manufacturing industries and other real economy are not essential to the development of domestic economy. The industrial transfer and overseas investment on basic manufacturing industry can make America access to lower labor costs and sales markets. At the same time, the modernization degree of the social security system is high, so people do not need to worry about retirement years. These features led to the low domestic savings rate of the U.S. The situation of China is quite opposite. China undertakes a lot of outsourcing and foreign industry transfer, and the financial industry in China is relatively weak. At the same time, domestic social security system in China is still in improvement stage, which is a common feature of transition society. People must save money for retirement and children's education. As a habit of East Asian population, the custom of saving money is also a reason for Chinese high saving rates.

Foreign investment factors behind China's trade surplus. On the surface, China's huge trade surplus has become a great symbol of Chinese benefit in international trade. But after carefully 
analyzing the foreign trade objects and methods, we find that actually, the benefit party of foreign trade surplus is not China. The proportion of China processing trade declined from $48.54 \%$ in 2000 to $32.69 \%$ in 2013. China has been in the position of low-end value-added processing and assembly link, while and high value-added sectors are taken by developed countries and core patent holders. This is our sore spot. After the reform and opening up, several generations of Chinese tolerate low wages and poor working environment, which accumulated the foundation of trade surplus. Foreign trade enterprises with foreign background have occupied half of Chinese foreign trade. Therefore, China does not benefit from specific perspectives.

\section{Empirical analysis on influencing factors of China's trade surplus with the United States}

Model establishment. Based on the causes of Sino-US trade friction and the availability of data, the period of 2000-2013 is chosen as the sample period. Within the period, Chinese trade surplus with the United States is explained as the explanatory variable (Y); factors include the United States domestic savings rate $\left(\mathbf{X}_{1}\right)$, China absorption FDI ( $\left.\mathbf{X}_{2}\right)$, the RMB exchange rate level $\left(X_{\mathbf{3}}\right)$, the number of US anti-dumping ( $\left.X_{\mathbf{4}}\right)$, Chinese dependence degree of foreign trade $\left(X_{\mathbf{5}}\right)$, the proportion of processing trade $\left(X_{\mathbf{6}}\right)$ are explanatory variables. Set up the model as follows

$$
Y_{t}=\beta_{0 t}+\beta_{1 t} X_{1 t}+\beta_{2 t} X_{2 t}+\beta_{3 t} X_{3 t}+\beta_{4 t} X_{4 t}+\beta_{5 t} X_{5 t}+\beta_{6 t} X_{6 t}+\mu_{t}
$$

Determining and testing of regression equation. In order to reduce multicollinearity and heteroscedasticity, we change the original model (1) into a model (2).

Co-integration test of time series. First of all, the author observes the timing sequence of each time series (Figure 1), and finds the time series are relatively stable.

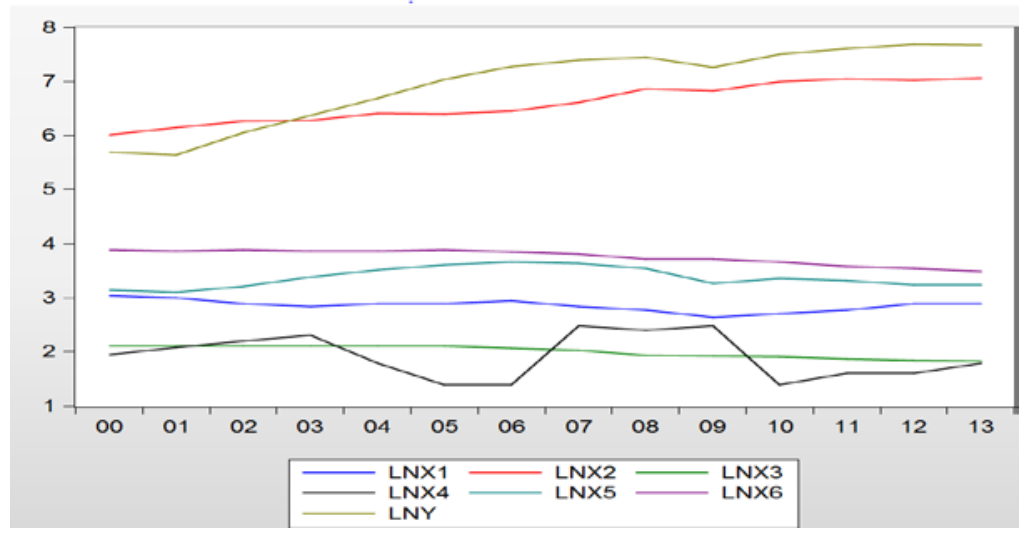

Fig. 1 timing sequence diagram of each variables

The stationary time series can be processed in co-integration test to further examine whether the linear combination of these variables have a long-term stable relationship. We regress the model (2) and carry out the unit root (ADF) test for the residuals (Figure 2).

Null Hypothesis: EADFXIEZHEN has a unit root

Exogenous: Constant

Lag Length: 0 (Automatic - based on SIC, maxlag=2)

\begin{tabular}{lccc}
\hline \hline & t-Statistic & Prob.* \\
\hline \hline Augmented Dickey-Fuller test statistic & -4.974556 & 0.0022 \\
\hline Test critical values: & $1 \%$ level & -4.057910 & \\
& $5 \%$ level & -3.119910 & \\
& $10 \%$ level & -2.701103 & \\
\hline \hline
\end{tabular}

Fig. 2 ADF test of residuals

It is found that the ADF value is less than the $\mathrm{T}$ value of $1 \%$ at a given level. Thus the original hypothesis is rejected, indicating that there is a long-run stable cointegration relationship among the variables. 
Co-linearity test and elimination. Co-linearity test. From regression results of the model (2), we can find that the coefficient of determination $R^{2}$ reaches 0.9854 , and model checking F-measure is significant. But there are a number of explanatory variables that are not significant, which embodies the distinctive characteristics of collinearity among the explanatory variables. This shows that the logarithm method cannot solve the problem of collinear. Therefore, we try to use the stepwise regression method to eliminate the problem and construct the appropriate model.

Elimination of co-linearity -- stepwise regression. First, we regress each explanatory variable (Table 1). We found that only the regression of $X_{\mathbf{2}}$ is significant, and the decision coefficient is large. So we use this variable as the basis to introduce second variables for regression (Table 2). We find that, the regression of $X_{2}$ with $X_{\mathbf{3}} 、 X_{2}$ and $X_{\mathbf{5}} 、 X_{2}$ are significant, but on the regression with $X_{\mathbf{2}}$ 与 $X_{\mathbf{5}}$, the coefficients are largest, and the interpretation of explanatory variables contribution are greatest. So the basis of that, we introduces the third variable and conduct regression (Table 3). We find that the after introduction the third variables, there are insignificant variables in all regression. So we eliminate variables $X_{1} 、 X_{\mathbf{3}} 、 X_{\mathbf{4}} 、 X_{\mathbf{6}}$ and establish the model (3) is as follows

$$
\ln Y_{=} \beta_{0}+\beta_{2} \ln X_{2}+\beta_{5} \ln X_{5}+\mu_{\mathrm{t}}
$$

Table 1 Regression results for each of the explanatory variables

\begin{tabular}{|l|l|l|l|l|l|l|}
\hline & $X_{\mathbf{1}}$ & $X_{\mathbf{2}}$ & $X_{\mathbf{3}}$ & $X_{\mathbf{4}}$ & $X_{\mathbf{5}}$ & $X_{\mathbf{6}}$ \\
\hline$\beta_{i}$ & $\mathbf{I} 4.07$ & 1.82 & $\mathbf{I} 5.08$ & $\mathbf{I} 0.48$ & 1.73 & $\mathbf{I} 3.84$ \\
\hline $\mathbf{t}$ & $\mathbf{I} 2.61$ & 7.62 & $\mathbf{I} 4.63$ & $\mathbf{I} 0.96$ & 1.69 & $\mathbf{I} 3.74$ \\
\hline$R^{\mathbf{2}}$ & 0.36 & 0.83 & 0.64 & 0.07 & 0.19 & 0.54 \\
\hline
\end{tabular}

Table 2 Rgression results of the second variable on the basis of

\begin{tabular}{|c|c|c|c|c|c|c|c|c|}
\hline & $X_{1}$ & $X_{2}$ & $X_{3}$ & $X_{4}$ & $X_{5}$ & $X_{6}$ & $R^{2}$ & \\
\hline $\begin{array}{l}X_{2} \\
X_{1}\end{array}$ & \begin{tabular}{|l|}
0.0096 \\
$(0.0086)$
\end{tabular} & $\begin{array}{l}1.82 \\
(5.47)\end{array}$ & & & & & 0.83 & 0.8 \\
\hline $\begin{array}{l}X_{2} \\
X_{3}\end{array}$ & & $\begin{array}{l}3.32 \\
(4.77)\end{array}$ & $\begin{array}{l}4.97 \\
(2.25)\end{array}$ & & & & 0.88 & 0.86 \\
\hline $\begin{array}{l}X_{2} \\
X_{4}\end{array}$ & & $\begin{array}{l}1.78 \\
(7.22)\end{array}$ & & $\left.\begin{array}{ll}\text { I } & 0.18 \\
(\mathrm{I} & 0.8\end{array}\right)$ & & & 0.84 & 0.81 \\
\hline $\begin{array}{l}X_{2} \\
X_{5}\end{array}$ & & $\begin{array}{l}1.78 \\
(16.38)\end{array}$ & & & $\begin{array}{l}1.46 \\
(6.95)\end{array}$ & & 0.97 & 0.96 \\
\hline $\begin{array}{l}X_{2} \\
X_{6}\end{array}$ & & $\begin{array}{l}2.91 \\
(5.83)\end{array}$ & & & & $\begin{array}{l}3.11 \\
(2.38)\end{array}$ & 0.89 & 0.87 \\
\hline
\end{tabular}

Note: $t$ value is in parentheses. 
Table 3 Regression results of the third variable on the basis of and

\begin{tabular}{|l|l|l|l|l|l|l|l|l|}
\hline & $X_{\mathbf{1}}$ & $X_{\mathbf{2}}$ & $X_{\mathbf{3}}$ & $X_{\mathbf{4}}$ & $X_{\mathbf{5}}$ & $X_{\mathbf{6}}$ & $R^{\mathbf{2}}$ & \\
\hline$X_{\mathbf{2}}$ & 0.65 & 1.89 & & & 1.52 & & 0.97 & 0.97 \\
$X_{\mathbf{5}}$ & $(1.36)$ & $(13.7)$ & & & $(7.34)$ & & & \\
$X_{\mathbf{1}}$ & & & & & & & & \\
\hline$X_{\mathbf{2}}$ & & 0.5 & $\mathbf{I} 4.13$ & & 2.08 & & 0.98 & 0.98 \\
$X_{\mathbf{5}}$ & & $(1.03)$ & $(\mathbf{I} 2.65)$ & & $(7.26)$ & & & \\
$X_{\mathbf{3}}$ & & & & & & & & \\
\hline$X_{\mathbf{2}}$ & & 1.74 & & -0.1 & 1.44 & & 0.97 & 0.96 \\
$X_{\mathbf{5}}$ & & $(15.9)$ & & $(0.35)$ & $(6.76)$ & & & \\
$X_{\mathbf{4}}$ & & & & & & & & \\
\hline$X_{\mathbf{2}}$ & & 1.16 & & & 1.87 & $\mathbf{I} 1.7$ & 0.97 & 0.97 \\
$X_{\mathbf{5}}$ & & $(3)$ & & & $(5.93)$ & $(\mathbf{I} 1.6)$ & & \\
$X_{\mathbf{6}}$ & & & & & & & & \\
\hline
\end{tabular}

Note: $t$ value is in parentheses.

Heteroscedasticity test. We test the model (3) with heteroscedasticity. After the regression, we use the White Test to examine heteroscedasticity (Figure 3). In the test, the associated probability is larger with the value of 0.7443 . Thus, the original hypothesis is accepted, namely there is no heteroscedasticity.

Heteroskedasticity Test: White

\begin{tabular}{llll}
\hline \hline F-statistic & 0.384402 & Prob. F(5,8) & 0.8464 \\
Obs*R-squared & 2.711964 & Prob. Chi-Square(5) & 0.7443 \\
Scaled explained SS & 0.598445 & Prob. Chi-Square(5) & 0.9881 \\
\hline \hline
\end{tabular}

Fig. 3 heteroscedasticity test (White test)

Autocorrelation test. We usually use the Watson - DW test to teste autocorrelation. We can find that the in the regression result of model 3, the DW value is 1.99. So there is no autocorrelation.

Empirical results. Finally, we establish the model, and the regression equation is as follows (the $T$ values of the corresponding variables are in parentheses.).

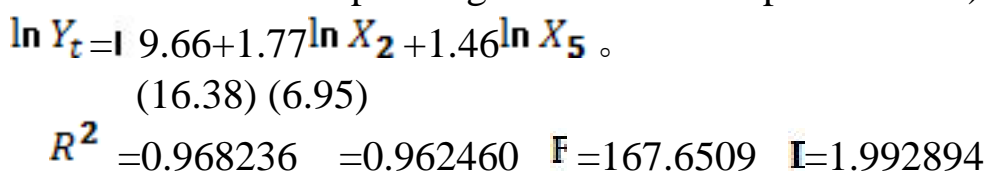

In summary, in the sample period, the main influence factors of surplus are FDI and Chinese small domestic demand (i.e. foreign trade dependence). If Chinese absorption of FDI increases 1\%, the trade surplus will increase $1.77 \%$. At the same time, if domestic demand increases $1 \%$ in China (i.e. dependence degree of foreign trade by $1 \%$ ), the trade surplus will decrease by $1.46 \%$. FDI and Chinese domestic demand explains Chinese trade surplus with the US for more than $96 \%$. Other factors, such as savings rate, the RMB exchange rate, the United States anti-dumping issues have extremely small influence on Chinese trade surplus with the US.

\section{Countermeasures and Suggestions}

According to the results of the empirical analysis, we put forward to following countermeasures.

China needs to optimize the quality of FDI and expand the profit of foreign investment. In the past, there was serious shortage in the Chinese capital. Foreign capital helped the development of China, and we also carried out policy of super national treatment to foreign investment. Now China has grown to a super power to attract foreign investment like the United States. Foreign capital utilized the cheap Chinese labors and huge market to make profit. However, foreign capital took a larger share of Chinese foreign trade surplus, while China had to face their accusations. Currently, domestic 
research on this issue has carried out, but not goes depth. There is no convincing data and conclusions. Thus, the Chinese government, enterprises, scholars should increase the intensity of research in this area. Only the sufficient evidence can help us to have public opinion on our side. At the same time, Chinese authorities should now pay more attention to the quality and direction of foreign countries. Before the full implementation of Pre-establishment National Treatment and Negative List System regulation in 2018, the central and local governments should take overall viewpoints, and use foreign capital which is conducive to optimizing economic structure and trade structure in China optimization.

China needs to further encourage, support and guide the expansion of domestic demand. From the perspective of economics, the issue of savings is a paradox. On one hand, high saving and low consumption can promote capital formation. On the other hand, Keynes believes that excessive savings and low consumption will lead to insufficient effective demand, which is not conducive to the increase of a national production. Thus, we should consider the current situation and trends of world economy under the background of high-speed domestic development and the "new normal" period. With the growing of domestic middle class, Chinese consumers have become regular consumers all over the world. Now China has conditions to expand domestic demand. While other counties in the world are still in post-crisis era, and their external demands are weak. Therefore, we should improve the construction of related system and security system to solve peoples' practical concerns, and then citizens will be willing to consume and invest. At the same time, we need to improve the product quality and service quality of domestic commodities to keep our customers inside.

American government should make efforts to balance international income, and consider the imbalance Sino-US trade objectively and fairly. The United States relies on its dollar hegemony to avoid its losses due to the imbalance payments. The usage of military forces leads to international condemnation. The imbalance international income of the United States is more political issue, and the United States need to correct these behaviors.

\section{References}

[1] C. Guedae, W.K. Won, The Trade imbalance between the United States and China: the role of exchange rate and trade liberalization, J. Agribusiness \& Applied Economics. 548 (2004) 1-2.

[2] T. Klitgaard, K. Schiele, The growing U.S. trade imbalance with China, J. Current Issues in Economics \& Finance. 3 (1997).

[3] Y. Lv, Research on the imbalance Sino-US trade under the background of economic globalization. Jilin University, 2013

[4] M.Z. Xu, Empirical analysis of the imbalance Sino-US trade from the perspective of industrial transfer, J. Journal of Beijing University of Technology (Social Sciences Edition). 4 (2009)

[5] J. Lv, Research on statistical differences of the imbalance Sino-US trade, Wuhan University, 2010. 